\title{
Mengkomunikasikan Pendidikan dan Melestarikan Kearifan Lokal Orang Bajo
}

\author{
Mukti Ali \\ Institut Agama Islam Negeri Salatiga \\ mukti1975@yaboo.co.id
}

\begin{abstract}
This research used ethnographic method on sea tribe, a sub-culture of Indonesian society commonly known by anthropologists with the term of the Bajo Tribe. The educational phenomenon of Bajo society has uniqueness, besides acknowledging that they only know, believe, and guided by the Islamic system, but in carrying out the main rituals of Islamic teachings are not visible, so is their awareness to go to bigher education is very difficult to realize in the understanding of society. For the People of Orang Bajo, education should not be lost from a value taught from generation to generation, and should not be lost from the life of their grandchildren. While formal education can be done enough for primary school (SD) only. Even if they can continue their education to a higher level, they are simply maintaining their values or education based on their local cultural wisdom. There are various findings of local wisdom that became the education identity of Bajo are Kampoh or togetherness in village, Lukka maintain the tradition of marriage, and Alla Tala have confidence in the power of God.
\end{abstract}

Keywords: bajo tribe, education, local wisdom, kampoh, lukka, Alla tala.

\begin{abstract}
Abstrak
Penelitian ini menggunakan metode etnografi pada mayarakat sub-kultur masyarakat Indonesia yang biasa di kenal secara antropologis dengan istilah Orang Bajo. Fenomena pendidikan yang ada pada masyarakat Bajo memiliki keunikan tersendiri, selain mereka mengakui bahwa mereka hanya mengenal, meyakini, dan berpedoman pada ajaran Islam, akan tetapi kesadaran mereka untuk mengenyam pendidikan ke arah yang lebih tinggi sangatlah susab terrealisasi dalam pemahaman masyarakat. Bagi Masyarakat mereka, pendidikan yang tidak boleh hilang adalah nilai yang diajarkan secara turun temurun dari generasi tua, dan tidak boleb hilang dari kehidupan anak cucunya. Sementara pendidikan formal dapat ditempub cukup menamatkan sekolah dasar (SD) saja. Jikapun melanjutkan sekolab ke jenjang yang lebih tinggi tidak lain hanyalah tetap mempertahankan atau melestarikan nilai pendidikan yang berdasar pada kearifan lokal budaya mereka. Terdapat berbagai temuan kearifan lokal yang menjadi identitas Masyarakat Bajo yaitu kampoh atau kebersamaan sekampung, lukka menjaga tradisi pernikahan, dan Alla Tala memiliki keyakinan akan kuasa Tuhan.
\end{abstract}

Kata Kunci: Suku Bajo, pendidikan, kearifan, kampoh, lukka, Alla tala.

Permalink/DOI:http://dx.doi.org/10.18326/infsl3.v11i1.187-206 


\section{Pendahuluan}

Pendidikan adalah salah satu bagian penting seharusnya menjadi perhatian dalam sebuah masyarakat, tidak terkecuali pada masyarakat pesisir, namun faktanya sangat berbeda. Terbukti dengan tingkat pendidikan masyarakat pesisir yang rendah. Rata-rata tingkat pendidikan masyarakat pesisir berhenti sampai batas SD dan hanya sedikit yang mengenyam pendidikan sampai tingkat SMP. Kondisi ini bisa saja dipengaruhi oleh berbagai faktor, diantaranya faktor regulasi, kesadaran, atau karena kurangnya sarana dan prasarana. Masyarakat Bajo di Kelurahan Bajo Indah Kecamatan Soropia merupakan kawasan pesisir yang mengalami hal serupa, padahal secara ekonomi daerah pesisir ini dapat menjadi dasar sumber pendapatan masyarakat daerah secara khusus dan Indonesia secara umum. Dengan potensi yang unik dan bernilai ekonomi, maka wilayah pesisir dihadapkan pada ancaman yang tinggi pula, maka hendaknya wilayah pesisir ditangani secara khusus agar wilayah ini dapat dikelola secara optimal dan seimbang terutama pada ranah pendidikan, agar terjadinya keseimbangan antara sumberdaya alam yang dimiliki sengan sumberdaya manusia. Bahkan kadang keterbelakangan dan yang menjadi hambatan dalam pengembangan potensi ekonomi adalah keterbatasannya sumber daya manusia yang ada di sana. Hal ini disebabkan oleh kurangnya antusiasme dan kesadaran masyarakat pesisir terhadap pendidikan dalam hal ini untuk mengembangkan pengetahuan mereka.

Hasil penelitian yang dilakukan oleh I Ketut Suardika dalam bukunya Problematika Pendidikan Suku Bajo, mensinyalir bahwa lemahnya akses pendidikan masyarakat merupakan bentuk keterpinggiran yang sangat dirasakan, akan tetapi semua ini karena perhatian pemerintah yang kurang, juga dari masyarakat sendiri. Ada kesan bahwa orang tua mereka kurang memotivasi anak-anaknya untuk sekolah. Ketersediaan SD dan SMP SATAP menunjukkan telah ada sarana pendidikan yang diharapkan dapat menampung anakanak usia pendidikan dasar sembilan tahun, walaupun memang kondisinya belum memadai, akan tetapi jika mereka memiliki keinginan dan kesadaran, maka segharusnya dapat mengarahkan anak-anak mereka untuk tetap bersekolah mulai dari SD sampai SMP. Kondisi ini menunjukan bahwa terdapat beberapa bentuk 
keterpinggiran yang berpengaruh terhadap akses pendidikan pada Masyarakat Suku Bajo yang kurang dalam pendidikan dasar, yaitu masalah sarana; baik ketersediaan guru maupun fasilitas lainnya. Bentuk dari keterbatasan berbagai kebutuhan pendidikan ini membuat beberapa orang tua siswa kurang begitu berminat untuk mendorong anak-anak mereka melanjutkan pendidikan ke jenjang yang lebih tinggi, baik dalam menamatkan pendidikan dasar 9 tahun maupun ke jenjang SMA. Bila dukungan lingkungan masyarakat sudah tidak berjalan dengan baik, maka keberlangsungan pendidikan tidak akan berjalan dengan lancar. (Suardika, 2014:43-44)

Akan tetapi, jika dilihat secara kultur, penyebab kurangnya antusiasme, kesadaran, regulasi, dan kurangnya sarana dan prasaran, tidak saja menjadi satu-satunya alasan sebagai penghambat pendidikan di wilayah tersebut, melainkan terdapat sikap kearifan lokal atau local wisdom yang mereka jadikan dasar bahwa pendidikan bukan sekedar formalitas semata. Local wisdom inilah yang kemudian mengharuskan mereka berada pada eksistensi kesederhanaan tanpa harus menempuh pendidikan yang lebih tinggi. Berpegang pada nilai lokalitas dan menjaga tradisi terdahulu dan secara turun temurun masih mempengaruhi cara pandang mereka.

\section{Diskursus Pendidikan dan Melestarikan Lokal Wisdom}

Penelitian H. Iin Wariin Basyari dalm Jurnal Edunomic. yang berjudulNilai-NilaiKearifanLokal (LocalWisdom) Tradisi MemituPada Masyarakat Cirebon (Studi Masyarakat Desa Setupatok Kecamatan Mundu). Berangkat dari fenomena semakin tereliminasinya unsurunsur budaya lokal pada masyarakat. Salah satu penyebabnya adalah arus modernisasi dan globalisasi segala aspek kehidupan termasuk tradisi dan budaya. Penelitian ini bertujuan untuk menemukan nilai-nilai kearifan (local wisdom), tradisi memitu pada masyarakat Cirebon. Penelitian ini menggunakan metode kualitatif dengan pendekatan fenomenologi. Hasil penelitian disimpulkan bahwa tradisi memitu (selamatan Nujuh Bulan) memiliki nilainilai kesadaran religi, psikologis kesehatan ibu hamil, dapat memelihara integritas sosial dan pelestarian budaya sebagai perwujudan identitas sosial dan budaya masyarakat (2014:47-56) 
Penelitian Takiddin dalam Jurnal Sosio Didaktika yang berjudul Nilai-Nilai Kearifan Budaya Lokal Orang Rimba (Studi Pada Suku Minoritas Rimba Di Kecamatan Air Hitam Provinsi Jambi). Memberikan gambaran tentang nilai-nilai kearifan lokal dalam budaya Orang Rimba di Kecamatan Air Hitam, Kabupaten Sarolangun, Provinsi Jambi. Bagi Takiddin Orang Rimba memiliki gaya hidup dan kepercayaan yang unik dan berbeda dari kehidupan masyarakat modern. Mereka memandang hutan sebagai tempat tinggal mereka. Salah satu kepercayaan Orang Rimba adalah jika ada orang yang meninggal dunia di tempat tinggal mereka, maka tempat itu dianggap sebagai daerah yang celaka bagi mereka dan mereka harus mencari tempat yang baru yang disebut "melangun". Kepercayaan inilah yang menjadi faktor utama yang mempengaruhi proses kehidupan Orang Rimba tidak menetap. Orang Rimba dianggap sebagai suku yang terbelakang, primitif, dan mudah dipermainkan. Namun, jika dipelajari dengan baik kandungan nilai dari budaya Orang Rimba ini banyak sekali terutama dalam perilaku mereka dalam menjaga kelestarian alam ( 2014:163-170)

Penelitian Ulfah Fajarini dalam Jurnal Sosio Didaktika yang berjudul Peranan Kearifan Lokal Dalam Pendidikan Karakter. menelaah tentang kekayaan kearifan lokal di Indonesia yang berperan dalam membentuk pendidikan karakter. Kearifan lokal hanya akan abadi kalau kearifan lokal terimplementasikan dalam kehidupan konkret sehari-hari sehingga mampu merespons dan menjawab arus zaman yang telah berubah. Kearifan lokal juga harus terimplementasikan dalam kebijakan negara, misalnya dengan menerapkan kebijakan ekonomi yang berasaskan gotongroyong dan kekeluargaan sebagai salah satu wujud kearifan lokal kita. Untuk mencapai itu, perlu implementasi ideologi negara (Pancasila) dalam berbagai kebijakan negara. Dengan demikian, kearifan lokal akan efektif berfungsi sebagai senjatauntuk membekali masyarakatnya dalam merespons dan menjawab arus zaman. Menggali dan melestarikan berbagai unsur kearifan lokal, tradisi dan pranata lokal, termasuk norma dan adat istiadat yang bermanfaat, dapat berfungsi secara efektif dalam pendidikan karakter, sambil melakukan kajian dan pengayaan dengan kearifan-kearifan baru. (2014:123-130) 


\section{Metode Penelitian}

Desa Bajo Indah, adalah tempat yang difokuskan dalam penelitian ini. Nama desa Bajo Indah adalah manifestasi kecintaan masyarakatnya atas perjalanan para pendahulu dan identitas mereka, Orang Bajo, Suku Bajo, atau Etnis Bajo. Desa Bajo Indah berada dalam wilayah administrasi kecamatan Soropia kabupaten Konawe yang berada di sebelah Pantai Timur kepulauan Sulawesi. Secara administratif kecamatan Soropia terdiri dari satu kelurahan dan duapuluh enam desa, baik yang sudah definitif maupun desa-desa yang masih berada dalam proses persiapan. untuk memperjelas lokasi tersebut sebetulnya lebih dekat dari pusat kota provinsi, Kota Kendari.

Desa Bajo Indah, memiliki sekitar 469 jiwa yang terdiri dari 156 kepala keluarga. Penduduk ini secara etnik memang tidak lagi termasuk pada etnik Bajo murni, karena sudah mengalami percampuran melalui pernikahan antaretnik, maupun terjadinya proses perpindahan penduduk dari luar etnis mereka. Sehinga dapat dipastikan karakter masyarakat Desa Bajo Indah tidak lagi homogen melainkan kelompok masyarakat yang heterogen. Perjumpaan saya dengan beberapa orang Jawa, Sunda, maupun yang lainnya di Desa Bajo Indah memperkuat heterogenitas masyarakat Bajo yang sangat terbuka dan memiliki karakter masyarakat yang multikultur yang masih banyak menimpan banyak person-person yang menjadi sumber untuk saya wawancarai, bahkan informan-informan itu beragam, baik dari masyarakat sendiri maupun dari lembaga-lembaga pemerintahan ataupun lembaga swasta. Bahkan tak sedikit wartawan yang datang untuk mendapatkan beberapa informasi tentang kegiatan-kegiatan masyarakat desa. Entah itu tentang kesehatan, ekonomi, dan sosial budaya. Tentang kehidupan Orang Bajo.

\section{Analisis}

Kampoh Mengkomunikasi Pendidikan dan Kearifan Lokal Bermasyarakat

Pada dasarnya penduduk Desa Bajo Indah mengakui bahwa mereka keturunan Suku Bajo atau masyarakat Bajoe Sulawesi Selatan yang hidup pada tiga zaman kerajaan besar di Sulawesi, yaitu 
kerajaan Luwuk, Goa dan Bone. Geopolitik yang terjadi pada ketiga kerajaan tersebut sangat kental dengan kehidupan masyarakat Suku Bajo awal, mengingat Suku Bajo adalah suku yang berada di laut dan sekaligus sebagai pintu gerbang kerajaan. Maka wajar kemudian ketika setiap pemerintahan tersebut menempatkan suku ini sebagai perisai dan angkatan perang kerajaan. Puncak pertempuran yang berkecamuk dan dengan berakhirnya kedaulatan kerajaan Bone, mengharuskan mereka juga kehilangan wilayah dan penghidupan, maka mereka berdiaspora menuju wilayah-wilayah menuruti kemana angin berarak. Pulau Bokori ini kemudian menjadi salah satu tempat mereka diami ketika berdiaspora. Pulau kecil yang ada di wilayah Soropia Sulawesi Tenggara.

Pada konteks hari ini, perpindahan dan diaspora dikarenakan semakain padatnya penduduk. Pulau sekecil itu hampir dipadati oleh rumah-rumah yang setiap satu rumah bisa mencapai 2-5 kepala keluraga, sementara setiap kepala keluarga memiliki anggota 1-5. Kemudian alasan lain adalah adanya keinginan Pemerintah Daerah untuk menjadikan pulau Bokori sebagai daerah wisata. Alasan pertama memang menurut hemat dan logika sangat wajar, karena bisa dibayangkan jika dalam satu rumah yang berukuran kecil dan sangat tidak layak harus dihuni oleh berjubelnya anggota keluarga. Selain privatisasi yang tidak terjaga pastilah persoalan lainnya akan hadir; Kedewasaan setiap anak yang sudah berkeluarga tidak tumbuh dengan baik. Tidak terbentuknya karakteristik keluarga yang bebas, kreatif, serta kesalingtergantungan antaranggota keluarga yang sangat terasa. Selain itu, struktur dan fungsi anggota keluarga dalam kerja dan tanggung jawab yang tidak tumbuh dengan baik.

Tidak ada perubahan yang sangat berpengaruh secara tiba-tiba. Setelah terjadinya perpindahan baik dari pulau yang padat maupun rumah sempit yang berjubel penghuni melahirkan persoalan baru yang mereka hadapi. Keberadaan yang melatarbelakangi tersebut masih menyisakan karakter-karakter mereka dalam menjalani kehidupan kemudian. Transisi dari sikap yang mengelompok dalam keluarga yang besar, sifat ketergantungan terhadap anggota keluarga yang lainnya, serta rasa tanggungjawab yang kurang terbangun menuju keluarga yang idial lambat terbentuk. Akan tetapi tidak dipungkiri, dari kekurangan tersebut ada imbas positif 
yang dapat membentuk masyarakat Suku Bajo. Kebersamaan dan sendi-sendi kekeluargaan yang sangat terbangun dengan kuat. Rasa peduli dan saling perhatian terhadap sesama sangat terasa. Kepedulian terhadap tetangga dapat dilihat dari keterbukaan untuk bertamu, meminta dan memberi beberapa hasil tanggakapan dari melaut, serta gotong royong untuk membangun atau sekedar memperbaiki rumah tetangganya. Konon, sebelum masyarakat Suku Bajo mendiami rumah yang mulai terlokalisir dan menetap di pinggiran laut, mereka menggunakan perahu sebagai rumah dan tempat aktifitas kehidupan mereka. Orang Bajo dahulu tinggal di rumah perahu tersebut tidak memiliki tempat yang tetap, maka tidak salah kemudian ketika mereka dikatagorikan pada masyarakat nomad. Perihal nomadennya masyarakat Suku Bajo dapat tercermin dari penjelasan Bapak Mukadi, bahwa kebiasaan Orang Bajo adalah berpindah-pindah tempat dari tempat satu ke tempat lainnya yang dianggap lautnya masih menyimpan banyak ikan atau kemana angin berhembus mendorong karoro; layar perahu yang terbuat dari anyaman daun pappas mereka, kesanalah arah yang dituju.

Desa Bajo Indah dibentuk oleh sistem perkampungan, kampoh yang terdiri dari bangunan-bangunan rumah yang semi permanen, dalam arti mereka sudah menetap dengan rumah yang tiang-tiangnya ditancapkan ke tanah, dinding-dindingnya dari papan kayu, beratap seng, asbes, atau daun rumbia. Bahkan sebagian penduduk sudah memiliki rumah yang berfondasi semen terutama bagi mereka yang berada di antara laut dan daratan. Perlu diketahui bahwa keadaan seperti ini sebagian besar atas bantuan pemerintah. Pemerintah daerah mencoba melakukan terobosan melalui bantuan-bantuan; seperti trans family, yaitu perpindahan penduduk dari keluarga besar -biasanya satu keluarga memiliki banyak kepala keluargadipecah ke rumah-rumah baru sederhana yang di bangun secara seragam. Struktur rumah yang berukuran enam kali enam meter ini dibagi pada dua bagian ruang, yaitu ruang bagian depan dan bagian belakang. Bagian depan dibagi menjadi dua, yaitu kamar tidur yang dipisahkan oleh dinding kayu dan ruang terbuka yang berfungsi untuk ruang tamu. Sedangkan bagian belakang difungsikan sebagai dapur dan tempat mandi yang keduaanya tidak dipisahkan oleh dinding pembatas. Jikapun terdapat pembatas hanyalah dinding 
kecil seadanya. Tidak ada jendela yang berukuran lebar pada rumah mereka kecuali di dinding depan ruang terbuka berukuran setengah meter persegi. Tak ada plafon rumah yang memisahkan antara atap dan lantai. Untuk menambah rasa aman dan artistik rumah, mereka menambahkan halaman kecil dari susunan kayu besi dan kayu putah berukuran sepergelangan tangan yang sekaligus berfungsi untuk menjemur pakaian dan menumpuk kayu bakar.

Sementara fasilitas jalanan dari kayu sebagai penghubung anata warga kampoh sudah mulai lapuk dan licin serta mulai tidak tertata kerapihannya karena sudah cukup lama umurnya, sehingga membentuk lobang-lobang membuat warga kadang harus mengalami kecelakaan. Sudah tak terhitung warga yang terkilir kakinya, bahkan banyak warga yang harus terperosok dan jatuh menimpa karang di permukaan laut dan akhirnya sampai pada kematian. Hal inilah yang terungkap dari ingatan Pak Mukading sebagai orang yang pertama memulai kehidupan di daerah itu. Tidak jauh dengan pengalaman orang-orang tua yang mengalami masa hidup krisis ini. Untuk menghubungkan rumah dan jalan mereka bangun dengan kayu dan sebelah darat dan jalan utama desa mereka gunakan tembok yang diperkuat degan batu karang. Berbagai bantuan dan perhatian dari berbagai pihak untuk ikut membangun jalan-jalan yang sedikit demi sedikit mulai mengalami perubahan. Proyek pemerintah sangat dirasakan oleh warga masyarakat Suku Bajo, begitupun uluran tangan dari lembaga-lembaga swadaya masyarakat (LSM) yang mendapat sambutan baik. Memang pada saat ini, Desa Bajo Indah sebagian besar jalanan penghubung ke rumah-rumah penduduk masih menggunakan kayu, walaupun bentuknya sudah memiliki nilai estetis dan lebih layak, konstruksi yang lumayan kuat disertai warna warni cat yang membungkus kayu-kayu tersebut.

\section{Lukka Mengkomunikasikan Pendidikan dan Nilai Kearifan Lokal Perkawinan}

Tidak jauh berbeda dengan budaya pernikahan atau acara pesta-pesta yang yang terjadi di daerah lain. Acara seremonial sebelum acara inti banyak dilakukan; bebenah tempat tinggal dengan berbagai dekorasi rumah, tenda terpasang, lampu-lampu 
diperterang, dan lain sebagainya. Keesokan hari acara dilanjutkan dengan ngaruntu, adalah acara kecil yang dihadiri oleh sesepuh kampung yang bertujuan untuk keselamatan persiapan pesta yang berguna menjaga keamanan peralatan pesta; piring, gelas, dan alat-alat lainnya sekaligus pemberitahuan pada masyarakat sekitar. Acara ini tidak jauh berbeda dengan bentuk selamatan-selamatan lainnya dalam tradisi sebagian umat Islam. Membaca tablil dan doa selamat diakhiri dengan mencicipi hidangan alakadarnya, baik kuekuehan maupun sekedar air putih atau teh. Setelah acara ngaruntu terlalui dilanjutkan pada acara mapaccing, yaitu acara selamatan yang diadakan sore hari dikhususkan untuk keselamatan mempelai terutama perempuan dengan peralatan rias sampai pada acara resepsi besok.

Pagi berikutnya, Bapak Kades mengajak saya untuk menghadiri acara tersebut kembali. Suasana formal nan sakral mulai terasa oleh saya, atmosfer magis menyelimuti kesaksian saya atas acara suci tersebut. Persiapan tuan rumah terpancar dari sekeliling rumah, sikap penantian keluarga mempelai perempuan tergambar dari petugas penyambut tamu yang sesekali keluar pagar halaman rumah menanti kedatanga keluarga memepelai laki-laki. Dalam waktu yang sama para sesepuh yang duduk di atas lammeh, tempat untuk para tetua yang disiapkan sebagai bentuk rasa hormat dalam setiap acara-acara pernikahan, khitanan, maupun acara-acara lainnya. Tempat ini dihiasi dengan berbagai hiasan dari daun kelapa dan peralatan dari kain yang memiliki motif sangat bagus. Mereka yang berada pada tempat ini adalah mereka yang dianggap terpandang baik dalam struktur pemerintahan, adat, maupun keluarga yang dianggap sesepuh. Mereka melakukan acara membaca barjanji silih berganti dengan irama, kemudian memanjatkan doa secara Islami. Hidangan berbagai macam kue-kue tertata dalam piring, sajian teh dalam gelas, dan secangir kelapa muda dicampur gula merah mulai disantap. Berbarengan dengan itu, diiringi dengan tabuhan gendang dan gong. Sederhana memang, dua gendang dan satu gong ditabuh dalam waktu lima menit tanpa ada nyayian.

Dupa mengepul dalam tembikar kecil menjadi tanda bahwa ini adalah acara sakral, dilengkapi dengan gelas berisi sirih dan pinang dan yang satunya gelas berisi air. Ada nilai filosofis dari 
fenomena tersebut. Baik dupa yang menyebarkan wangi kemenyan dan tabuhan gendang dan gong adalah bentuk kontestasi bagi halayak masyarakat luas guna mengabarkan adanya sebuah acara suci. Menurut Mircea Eliade dalam Nurdinah Muhammad dalam Jurnal Substantia yang berjudul Memahami Konsep Sakral dan Profan dalam AgamaAgama, mengatakan bahwa agama adalah suatu sistem yang timbul dari sesuatu yang disakralkan. Agama diposisikan sebagai sesuatu yang konstan, sebagai suatu elemen dalam kehidupan manusia. Fungsi agama dilihat sebagai sebuah sebab bukan akibat; kehidupan yang profan adalah wilayah kehidupan sehari-hari, yaitu hal yang dilakukan secara teratur dan tidak terlalu penting. Sedangkan yang sakral adalah wilayah yang supranatural yang tidak mudah dilupakan dan sangat penting. Sesuatu yang sakral adalah tempat dimana segala keteraturan dan kesempurnaan, juga tempat berdiamnya roh-roh para leluhur, para kesatria dan dewa (Muhammad, 2013:271).

Tamu-tamu lelaki berada di ruang bagian depan, sementara tamu-tamu perempuan berada di ruang bagian tengah. Dalam waktu yang lama rombongan mempelai laki-laki tiba di depan rumah mempelai perempuan. Kedatangan mereka disambut dengan taburan bunga yang dicampur dengan butiran-butiran beras dalam sebuah tempat yang dibawa oleh orang dari pihak mempelai perempuan. Bagian barisan depan terdiri dari pengantin laki-laki yang digandeng oleh moa pananga yaitu orang yang membawa maskawin atau berupa barang bawaan khusus dari pihak laki-laki untuk diserahkan pada mempelai perempuan. Kemudian diikuti oleh orang-orang dekat mempelai laki-laki; orang tua, kakak, adik, paman, dan barisan selanjutnya adalah mereka perempuan-perempuan cantik dengan pakain kebaya seragam dan polesan mike-up pembawa barang-barang seperti buah-buahan, kue-kuehan, dan lain-lainnya. Mempelai perempuan belum juga keluar dari kamarnya dan tidak ikut menyambut kedatangan calon suaminya. Pengantin perempuan tetap sosok yang belum boleh dipertemukan dengan calon mempelai laki-laki. Setelah acara penyambutan usai, memepelai laki-laki langsung diajak ke ruang tengah yang disiapkan dengan alas duduk kasur yang dibungkus dengan kain bermotif batik sekaligus meja kecil dengan kesiapan seorang petugas pencatat nikah serta saksi nikah sekaligus disaksikan oleh semua sesepuh yang hadir tadi. 
Lanjutan dalam acara pernikahan itu terdapat acara lukka dalam tradisi Orang Bajo. Tradisi adat yang bermaksud pembatalan wudlu. Dalam bahasa agama adalah meniadakan keharaman -mubrim-. Ketika lukka ini terjadi maka pihak pengantin laki-laki masuk ke kamar pengantin perempuan yang menunggu sejak dimulainya acara resepsi sampai adanya proses ijab dan qabul. Sesampai di dalam kamar, pengantin laki-laki diperbolehkan menyentuh bagian tubuh pengantin wanita. Dalam Islam atau bahkan agama lainpun akan halallah perempuan ketika sudah terjadi ijab qabul. Salah satu acara adat yang saya rasakan betapa tingginya penerjemahan dan interpretasi mereka terhadap ajaran Islam yang satu ini. Lukka dan pernikahan adalah simbolisasi sekaligus manifestasi dari penyatuan dua individu yang memiliki komitmen dalam membentuk ikatan yang didalamnya ada norma biologis, norma cinta, selain norma kemanusian yang sangat fundamental.

\section{Alla Taala; Mengkomunikasikan Pendidikan dan Teologi Orang Bajo}

Selalu ada yang menarik bagi siapa pun, ketika berada di pinggir pantai atau pesisir. Selain keindahan alam, debur ombak yang saling kejar mengejar, susul menyusul, ditambah melodi harmonis percik buih putih. Di atasnya hembusan angin laut yang identik dengan aroma garam yang kadang terpanggang matahari sepanjang hari. Burung-burung pemakan ikan kadang hinggap di tiang bedera perahu para nelayan. Di kejauhan terdengar sura azdan Ashar mengingatkan manusia bahwa matahari akan segera tenggelam di lembah perbukitan yang berada di sebelah Desa Bajo Indah. Sebentar lagi kegelapan akan tiba jika bulan ditakdirkan untuk sementara waktu tak harus menampakkan diri.

Desa Bajo Indah berada jauh dari hingar bingar kota. Tak terbersit dalam pikiran, mata, telinga, adanya kebisingan mesinmesin alat transportasi seperti mobil dan motor yang melintas di jalanan. Apa lagi keramaian dan hiruk-pikuk masyarakatnya seperti yang terjadi pada masyarakat secara umum. Kehidupan mereka layaknya kehidupan pesantren tradisional pesisir yang pernah saya temui di beberapa tempat di daerah kelahiran saya dua puluh tahun yang lalu. Memang biasanya pesantren-pesantren itu berada jauh 
dari keramaian kota maupun keramaian daerah-daerah yang penuh dengan aktivitas manusia. Alasan kenapa saya mengibaratkan keberadaan mereka dengan sebuah pesantren yang begitu sepi dan begitu kental dengan atmosfer keislaman. Pikir saya dalam hati, untuk menemui Tuhan tidak harus berada dalam kemajuan modernitas yang diwakili oleh berbagai fasilitas yang serba berlebihan, tidak juga harus memiliki sikap keluasan dalam proses keterbukaan segalanya. Informasi yang diproses secara mekanik tidak menjamin percepatan menuju hadapan Tuhan. Tuhan dapat digapai melalui keterbatasan fasilitas yang digandrungi oleh sebagaian besar penduduk dunia ini.

Tuhan hadir dalam kerinduan dan kebersihan hati bagi si pengharap kedatangan-Nya. Dalam keterbatasan fasilitas, bangunan masjid yang sederhana jauh dari kemegahan yang pernah saya temui di beberapa daerah. Tidak ada kubah masjid yang mengkilap berwarna keemasan. Ia hanya beratapkan seng yang jika siang hari menambah panasnya ruangan masjid, berlantaikan tegel tua dilapisi sajadah yang dibawa oleh masing-masing orang. Pengeras suara dengan alakadarnya berusaha memanggil dengan kalimat agung timbul tenggelam tersapu keras dan lemahnya angin, yang mampu menggugah dan menghapus rasa kepenatan yang mereka lalui dalam kehidupan. Kekhusyu'an shalat para penunainya, Orang Bajo, mencerminkan keterserahan sepenuhnya pada pemilik jiwa-jiwa. Khidmat dalam aroma magis menghantarkan saya menuju tangan Tuhan. Runutan gerakan shalat mengalir memenuhi ruangan masjid yang dipimpin sang imam hingga akhir. Bacaan surat pembuka disambung dengan surat-surat pendek al-Quran walau bacaannya tidak begitu sempurna, tapi ini melebihi dari cukup mengingat tak banyak orang pandai dalam teori agama di antara mereka. Tapi saya yakin secara praktik mereka jauh lebih ikhas menjalankan dalam keterbatasannya. Allabu Akbar kami hadapkan wajah ini pada Sang Pencipta langit dan bumi dengan sepenuh rasa serah diri.

Anak-anak kecil Suku Bajo dengan sarung dan pakaian rapi menembus debu pesisir yang tertiup angin tidak menggoyahkan rasa kerinduan mereka pada sang khaliq-Nya. Tubuh-tubuh kecil itu berada pada barisan-shaf-tersendiri. Mengelompok secara alamiah tanpa harus diatur. Sebuah pelajaran tersendiri bagi saya bahwa dalam rutinitas ritual keagamaan pun mereka membentuk 
kelompok sendiri sesuai dengan dunia mereka sendiri. Putih dan hitamnya anak-anak kembali pada fitrah dan lingkungan yang mereka singgahi. Keterpencilan dan ketersendatan arus informasi menjadikan mereka tidak begitu mudahnya menerima kemajuan jaman yang semakin tidak menentu arahnya, sehingga selain nilainilai budaya positif yang lamban berkembang juga niali-nilai budaya negatif tidak banyak berpengaruh terhadap mereka. Hiburan-hiburan dan dunia gemerlap seakan tidak pernah bisa mencerabut nilai-nilai fundamental yang diwariskan dari tetua mereka. Sikap individualis nyaris tak terlihat dari kehidupan mereka. Selepas sekolah dan bermain mereka dapat dikumpulkan paling tidak melalui jumlah shalat yang dilakukan secara berjamaah di masjid. Pendidikan baca tulis al-Quran serta ilmu-ilmu agama juga diperolehnya dari tempat di mana mereka bersujud merendahkan jiwa raga dihadapan yang Maha Tinggi.

Warisan keislaman dari orang-orang terdahulu mereka disimpannya secara rapi dalam sanubari mereka. Islam yang mereka yakini adalah Islam yang tidak boleh diperdebatkan layaknya Islam yang saya alami ketika tercatat sebagai bagian dari masyarakat yang mengkritisi Islam. Sehingga jika saya merenung ada benarnya bahwa Islam bukan sesuatu yang layak untuk diperdebatkan apalagi harus menyekat diri dari orang-orang Islam yang berbeda secara pemahaman. Secara historis Islam terbagun dari beberapa pemahaman yang telah lahir.

Keterasingan secara sosial tidak serta merta memposisikan mereka terasing dari keberadaan Sang Penguasa Alam. Keterasingan membuat kehidupan keagamaan mereka lebih mandiri. Ajaran agama jelas tercurah dalam kehidupan Masyarat Bajo. Keseimbangan antara kehidupan duniawi dan ukhrawi seakan menjadi karakteristik masyarakat yang jauh dari peradaban. Seperti apa yang ditulis oleh Nurcholish Madjid dalam Masyarakat Religius; Dalam percakapan hidup sehari-hari, di tengah-tengah masyarakat sering muncul ungkapan 'urusan dunia' dan 'urusan akhirat' (kadang kala urusan akhirat disebut juga urusan agama). Hal ini mengindikasikan bahwa manusia membedakan antara keduanya dan senantiasa ingin memperoleh kesuksesan dalam kedua urusan tersebut. Seperti yang selalu disampaikan dalam do'anya, manusia 
selalu memohon pertolongan kepada Allah untuk mendapatkan keberhasilan dalam urusan dunia dan akhirat (agama). Artinya manusia tidak ingin hanya memperoleh keberhasilan dalam salah satu urusan saja (dunia tidak akhirat atau akhirat tidak dunia) melainkan ingin keberhasilan keduanya sekaligus (Madjid, 1997:181). Memang hal itu tidak disadari secara jelas oleh mereka, karena ada kalanya dari mereka memaknai antara kehidupan dunia dan kehidupan akhir adalah sendiri-sendiri mengingat pemaknaan yang sederhana bagi mereka bahwa ibadah adalah sebuah kewajiban dan itu berada pada wilayah ketuhanan. Sementara sebuah usaha atau kehidupan keseharian hanya dimaknai sebagai sebuah kebutuhan untuk menjaga keberlangsungan hidup serta mengikuti gerak budaya yang sampai pada pola berfikir mereka.

Perahu-perahu mereka tambatkan di pinggir pantai di belakang rumah mereka. Penjemur ikan asin, pemilik warung, juga anak sekolah bersiap mengambil air wudlu dan bergegas ke masjid seperti hari-hari yang sudah-sudah. Tidak ada rasa khawatir untuk sejenak meninggalkan rutinitas ekonominya. Semua percaya sesamanya karena semua seakan tunduk pada aturan yang terakumulasi dari individu-individu yang berserah diri pada Empunya. Sekali lagi, saya hanya mengelus dada luruh dalam rasa. Sebuah komunitas manusia yang jauh dari kecurigaan, kegamangan, ketakutan seperti yang terjadi pada masyarakatmasyarakat yang dikatagorikan berbudaya. Semuanya berjalan seperti pada negeri dongeng yang makmur, sejahtera, berwibawa, negeri yang membawa kedamaian. Ikhlas dan serah diri. Itu bahasa yang sangat membuat lidah kita kelu karena terlalu sering mengucapkannya. Walau tidak dipungkiri sebagian kita baru bisa melafalkannya dan belum bisa merasakannya. Berbeda dengan apa yang saya temukan pada saudara kita yang anak-anaknya mayoritas hanya mengenyam pendidikan sekolah dasar (SD) atau sedikit anak-anak yang sampai di tingkat menengah atas dan orang-orang tuanya yang hampir semuanya tidak mengenyam pendidikan formal atau tamat esde saja.

Masyarakat Suku Bajo hampir keseluruhan beragama Islam, akan tetapi pada praktek kepercayaan dan keyakinannya masih mempercayai beberapa mitos yang bersumber pada alam yang 
berada pada alam mereka. Tidak jauh berbeda dengan beberapa penganut agama Islam yang berada di darat. Pada awal abad ke-20 penduduk Kendari telah menganut agama Islam. Bahkan Orang Bugis dan Orang Bajo sebelum menjadi penduduk Kendari telah memeluk agama Islam. Namun walau sudah memeluk agama Islam tetapi juga masih mempunyai kepercayaan-kepercayaan animisme. Animisme ialah mempercayai bahwa setiap benda di bumi seperti kawasan tertentu, gua, pohon atau batu besar mempunyai jiwa yang mesti dihormati agar tersebut tidak mengganggu manusia, malah membantu mereka dari jiwa dan roh jahat dan juga dalam kehidupan seharian mereka (Kasimin, 1991:27). Orang Bajo tetap sampai sekarang taat menganut agama Islam, dan bagi mereka Islam adalah satu-satunya agama yang menjadi ciri khas suku ini. Menjaga kekayaan laut adalah salah satu sifat yang diemban oleh Suku Bajo. Bersama dengan kearifannya mereka mampu menyesuaikan diri dengan ganasnya lautan.

Malam itu angin laut berhembus menyusuri sela-sela dinding rumah. Mbok Uti dan lebih sering dipanggil dengan Mbuti duduk di lantai dapur yang beralaskan tikar pandan, dan melipat kedua kakinya menyerupai jongkok. Punggungnya yang sudah termakan usia disandarkan pada tiang kayu penyanggah atap rumah. Saya duduk di sampingnya sambil sesekali bertanya tentang kehidupan yang telah, sedang, dan akan dijalaninya. Karena saya menganggapnya Mbuti dan wajar menganggapnya sebagai generasi tertua di desa Bajo. Mbuti atau yang lebih susah dilafalkannya dengan mbah uti tidak berbeda dengan kebanyakan Orang Bajo yang lainnya. Ia sangat mahir bercerita dengan menggunakan bahasa Indonesia. Sesekali juga saya menanyakan padanan kata atau peristilahan yang sesuai dengan Bahasa Bajo. "Cepu Arba; hari rabu dipenghabisan bulan. Pada hari ini dilarang melakukan kegiatan yang berbentuk mendirikan rumah, melaut, dan kegiatan-kegiatan lainnya. Banyaknya pamali pada hari tersebut" Tutur Mbuti' . Pamali bagi Orang Bajo berkonotasi sebuah larangan dan jika dilakukan larangan tersebut akan mengakibatkan berbagai kejadian yang tidak diinginkan. Zacot juga menemukan pamali dalam kebingungannya ketika di lapangan menemukan kalimat tersebut. Akan tetapi kemudian ia 
dapat memaknainya seperti yang dipahami masyarakat Suku Bajo. Pamali adalah larangan yang berkaitan dengan perbuatan tertentu dalam situasi-situasi yang berbeda. Misalnya menyangkut semua penghuni sebuah rumah tempat adanya seseorang yang sedang sakit. Mereka tidak dapat memberi atau membeli makanan. Pamali ini berlangsung selama tiga hari. Orang tidak boleh menunjuk pelangi dengan jari kaku dan bengkok karena jari itu akan benarbenar menjadi bengkok, dan tambahan lagi, orang bisa jatuh sakit; dan anak-anak juga terkena penyakit kandalo (bintil-bintil). Orang juga menyebut pamali jika tidak dapat keluar desa, setelah bendera putih ditancapkan di depan gerbang pintu masuk desa pada saat terjadi epidemi. Serupa dengan penemun Anwar Hafidz dalam hasil penelitiannya tahun 2007, Manajemen Pemberdayaan Perempuan: Perubahan Sosial Melalui Pembelajaran Vokasional Skill pada Keluaga Nelayan Bajo, menjelaskan bahwa perjalanan waktu juga menjadi perhatian utama mereka dalam melakukan suatu kegiatan, bulan baik adalah Bulan Zulhijjah, dan Rajab. Sedangkan bulan pantangan adalah Bulan Muharam, Safar, Zulkaidah, dan hari Rabu terakhir pada setiap bulan Qomariah. Selain itu, juga diperhatikan waktu dengan melihat air pasang, dan umumnya kegiatan mereka diawali pada saat air pasang dengan asumsi supaya meningkat rezekinya.

Kegiatan pernikahan umumnya hari Jumat sebelum Dzuhur. Sedangkan pindah rumah dilakukan umumnya hari Minggu subuh sebelum ayam turun dari tempat bertenggernya, dengan harapan supaya rumahnya kelak ditempati dalam keadaan tenang, tentram, dan damai sekeluarga. Pendirian rumah dilakukan awal naik pasang dan pada hari minggu dan awal bulan (ompoo lolo). Sementara, dalam tradisi untuk memulai kegiatan melaut Orang Bajo mengadakan ritual mantra-mantra dengan menyertakan beberapa barang, seperti daun sirih, pinang, dan tembakau. Adat ini dinamakan luppisa. Bentuk luppisa biasanya dibuat biasa dan sederhana, pinang dan tembakau disimpan di atas daun sirih dan kemudian dilipatnya. Dalam melipat daun tersebut tidak ada ketentuan yang penting kesemuanya bisa membentuk satu kesatuan dan tidak terceraiberai. Tujuannya adalah untuk meminta ijin pada pemilik laut yang mereka sebut dengan Mbo Lao (neneknya yang memiliki laut). 
Mereka memiliki keyakinan jika lipatan daun sirih tersebut langsung dijemput oleh seekor kepiting, maka diyakini bahwa permohonan itu diterima. Dengan demikian terbebas dari marabahaya dan akan mendapatkan hasil tangkapan yang berlimpah. Jika hal ini luput dari Orang Bajo, maka malapetaka itu bisa terjadi seperti timbulnya penyakit pusing, muntah, karam, dan tidak mendapatkan hasil. Untuk menghilangkan kejadian tadi mereka harus melakukan hal yang serupa, yaitu melakukan luppisa.

Ada juga yang disebut bantam pamali, yakni setelah bersalin harus diberikan ramuan dari campuran kelapa, beras, dan kunyit yang diusapkan pada seluruh bagian tubuh pesalinan. Bantam pamali ini yang kemudan akan menjadi rebutan bagi keluarga atau orang lain yang masuk ke dalam rumah tersebut. Hal ini dimaksudkan untuk menjaga dan mencegah rematik, rabun mata, dan penyakit lainnya.

Dari hasil obrolan dengan Mbuti, banyak hal-hal yang disampaikan beliau terutama mengenai adat istiadat serta kepercayaan yang masih dipegang teguh masyarakat Bajo. Ada beberapa kepercayaan yang dapat saya rangkum sebabagai berikut; Jika pergi ke mana saja, terutama menggunakan perahu, tidak boleh terdiri dari tiga orang bersaudara. Jika ini dilakukan diyakini salah satunya akan menjadi tumbal, bahkan kecelakaan akan menghampiri semuanya. Kalau hujan tidak boleh tertawa terbahak-bahak, ini akan menyebabkan posisi mulut menyebelah atau penyok karena dicubit oleh piu nyarih. Selain itu, kepercayaan Orang Bajo yang berhubungan dengan musim hujan dan terdapat bukkoh yang berarti pelangi yang dilarang membelakanginya terutama wanita hamil. Karena jika membelakanginya akan menyebabkan susah dalam proses persalinan, bayi yang berwarna kuning baik kuku, mata, maupun air seninya. Jika pun hal ini sudah terlanjur karena biasanya Orang Bajo berada di atas perahu dan dalam keadaan mendayung, sehingga membelakangi bukkoh tersebut maka harus memanjatkan mantra dalam Bahasa Bajo "Nabi eja dipamenteng palai kite mebundaangku dalleku aku mamie iyyea dallete kite mamie iyyea", arti secara sederhananya adalah kita (kamu dalam bahasa Indonesia yang bernilai penghormatan) minggir di depanku rizkiku saya yang cari rizkimu kamu yang cari. 
Dalam kepercayaan Orang Bajo di sekitar kehamilan dan kehidupan bayinya terlihat dari beberapa tradisi; sangkineh: ajimat yang terbuat dari doi benggol, uang logam yang berlubang yang dijadikan karompah baik gelang atau ikat perut atau pinggang. Ariari (tamuni) dibuang di laut agar tidak kagetan, apapun yang terjadi pada orang tuanya tidak berpengaruh pada anak itu. Biasanya ini terjadi pada keluarga yang mencari nafkahnya di laut atau nelayan. Dan jika orang tuanya bekerja di darat maka ari-ari itu ditanam di darat. Panindak tana atau menginjak tanah yaitu menginjakan bayi yang akan mulai berjalan. Setelah pesalinan sang bayi di gendong selama tujuh hari tujuh malam diselimuti tujuh lapis kain dan dilepas setiap satu kain satu hari. Jika istri akan melahirkan dianjurkan seluruh yang terkunci untuk dibuka, kunci lemari, gembok, bahkan celana dalam sang suami. Ini agar memeperlancar proses persalinan. Selama tujuh hari dari proses persalinan sang ayah dilarang melaut karena roh anak akan mengikutinya. Jika pun harus pergi, maka harus memotong secuil rambutnya dan disimpan di rumah. Kekuatan ruh juga, sangat kentara dalam kepercayaan Orang Bajo. Dipalu bajonga (dipanggil rohnya yang hilang) karena biasanya orang yang setelah sakit panas dingin atau trauma pada suatu benda atau kejadian, maka dipanggilnya roh tersebut tergantung penyebab apa atau barang apa yang dia takuti. Duatah atau ramalan bisa melihat keadaan yang berlayar di jauh sana. Melalui media dukun yang memanggil roh. Ketika roh masuk ke tubuh dukun (trans), maka si pasien yang ingin mengetahui keluarganya yang melaut bisa bertanya pada si roh itu dan dukun itu akan menjawabnya melalui bahasa. Bahkan diyakini hal itu dapat dijadikan meramal nasib masa yang akan datang. Sebaliknya orang yang di laut seorang suami dapat membaca tanda alam, jika suasana tenang di laut, tiba-tiba melihat segerombolan ikan seperti mabuk sakit. Hal ini ditafsir ada kejadian marabahaya pada keluarga di rumah, bisa sakit bahkan meninggal.

\section{Kesimpulan}

Ada secercah pendidikan dan pelajaran yang saya dapatkan dari pengalaman hidup berBajo masyarakat Suku Bajo, yang sekaligus dapat menjadi refleksi saya kemudian. Masyarakat Suku Bajo adalah 
masyarakat yang tidak bisa lepas dari debur ombak dan putihnya buih yang diperkuat oleh melodi suara burung pemakan ikan. Suatu masyarakat yang memiliki aturan berperilaku, serta memiliki pola pikir yang didasarkan pada fenomena alam yang mengitarinya. Karakter dan sikap mereka tidak jauh berbeda dengan mereka yang berada di wilayah kepulauan di seluruh nusantara. Terkecuali sebagian kecil dari mereka yang menjadikan mereka dipandang unik atau berbeda dengan masyarakat lainnya. Sistem perumahan yang mereka bangun dengan teknik menancapkan tiang-tiangnya di atas lautan. Hal ini adalah ciri umum dan utama dari masyarakat Suku Bajo. Bagian rumah pasti selalu berhubungan dengan laut. Walaupun ada bererapa rumah yang mengkombinasikan antara daratan dan lautan.

Sistem kekerabatan dan kekeluargaan merupakan ciri lain yang membedakannya dengan kelompok atau suku lainnya. Umumnya kekeluargaan mereka sangat kuat sehingga sikap tenggangrasa dan saling menolong yang terus terjaga. Sehingga kesan individualitas yang tidak kentara. Sederhana, tidak ada tanda-tanda kemapanan walau sebenarnya mereka bisa dan mampu untuk merealisasikannya dengan sedikit hidup hemat dan tidak boros, memenej pola kehidupan, menjaga apa yang menjadi faktor utama penopang hidup mereka, dan melihat masa depan yang akan ditapaki.

\section{Daftar Pustaka}

Basyari, H. Iin Wariin, Nilai-Nilai Kearifan Lokal (Local Wisdom) Tradisi Memitu Pada Masyarakat Cirebon (Studi Masyarakat Desa Setupatok Kecamatan Mundu) Jurnal Edunomic Volume 2 No. 1 Tahun 2014

Bohannan, Paul, and Mark Glazer, edit. 1973. High Points in Anthropology, alfred A. Knopf, New York,

Burhanuddin, B., Dkk. 1986/1987. Dampak modernisasi Terhadap Hubungan Kekerabatan di Sulawesi Tenggara, Depdikbud Kanwil Provinsi Sultra Proyek invetarisasi dan Dokumentasi Kebudayaan Daerah,

Chou, Cynthia. 2003. Indonesian Sea Nomads, Money, Magic, and Fear of The Orang Suku Laut, RoutledgeCurzon, NY. 
Daeng, Hans J. 2008. Manusia, Kebudayaan dan Lingkungan Tinjauan Antropologis, Pustaka Pelajar, Yogyakarta,

Fajarini, Ulfah, Peranan Kearifan Lokal Dalam Pendidikan Karakter, Jurnal Sosio Didaktika: Vol. 1, No. 2 Des 2014

Geertz, Clifford. 1992. The Interpretation of Cultures, Kanisius, Yogyakarta,

Hafidz, Anwar. 2007. Manajemen Pemberdayaan Perempuan: Perubahan Sosial Melalui Pembelajaran Vokasional Skill pada Keluaga Nelayan Bajo. Alfabeta, Bandung.

Kerja Bajo Badan Riset Daerah Pov Sultra Dengan Unhalu, Kajian Komprehensif Untuk Mendukung Sultra Raya 2020 (Pendekatan Gerakan Kebudayaan dan Peradaban), 2003

Koentjaraningrat.2007. Manusia dan Kebudayaan di Indonesia, Penerbit Djambatan, Jakarta.

Lewis, I.M. 1985. Social Anthropology in Perspective, the Relevance of Social Anthropology, Cambridge University Press.

Madjid, Nurchalish.1997. Masyarakat Religius, Jakarta: Paramadina. Muhammad, Nurdinah, Memahami Konsep Sakral dan Profan dalam Agama-agama, Jurnal Substantia Vol. 15, No. 2, Oktober 2013

Sagimun, dan Rivai Abu. Edit 1980/1981. Sistem Kesatuan Hidup Setempat Daerah Sulawesi Tenggara, Depdikbud Proyek invetarisasi dan Dokumentasi Kebudayaan Daerah.

Salman, Darmawan, Jagad Maritim. 2006. Dialektika Modernitas dan Akulturasi Kapitalisme pada Komunitas Konjo Pesisir di Sulawesi Selatan, Ininnawa, Makassar,

Sopher, David E. 1977. The Sea Nomads, A Study of the Maritime Boat People of Southeast Asia, the National Museum Singapura,

Spradley, James P. 1997. Metode Etnografi, terj., Tiara Wacana, Yogyakarta.

Suardika, I Ketut, Problematika Pendidikan Suku Bajo, Ombak, Yogyakarta, 2014

Takiddin, Nilai-Nilai Kearifan Budaya Lokal Orang Rimba, Jurnal Sosio Didaktika: Vol. 1, No. 2 Des 2014

Zacot, Francois Robert. 2008. Orang Bajo Suku Pengembara Laut Pengalaman seorang Antropolog, terj., KPG, Jakarta. 